\title{
MAKING DEMOCRACY WORK? \\ Quasi-Public Entities and the Drama of Elections in Ghana
}

\section{Richard Asante}

\author{
Dr Richard Asante is a Research Fellow in the Institute of African Studies, \\ University of Ghana, Legon \\ e-mail: richasagh@yahoo.com
}

\begin{abstract}
Since Ghana made the transition to multiparty democracy in the early 1990s there has been a progressive improvement in electoral management and the acceptance by the political players of election results. Six successive elections have been held so far, with two crucial power alternations between two hostile political parties in 2001 and 2009. The 2012 elections presented an opportunity for the country to continue along the path of democratic consolidation. However, the outcome of the elections was vigorously disputed and contested in court by the main opposition party, nearly bringing the country to the brink of violence. This article makes a contribution to ongoing debates about why some elections pass peacefully and results are accepted, while others do not. Various studies have focused on the role of formal institutions in ensuring credible and fair elections. This article, however, emphasises the importance of informal institutions in explaining variations in electoral outcomes and legitimacy in Ghana.
\end{abstract}

\section{INTRODUCTION}

Since the restoration of multiparty democracy in the early 1990s the electoral path has emerged as the only means of choosing political leaders and disposing government in Ghana's political system. The extent to which Ghanaians have embraced the electoral system as a means of delivering national goals and political stability is reflected in high voter turnouts, sometimes reaching $80 \%$.

After 1992 Ghana turned its back on the constitutional instability that had characterised the country's political history, particularly from 1966 to 1991, when, political power oscillated between civilian and military regimes.

With an enviable record of six successive presidential and parliamentary elections (1992, 1996, 2000, 2004, 2008 and 2012) and two crucial alternations of power, in January 2001 and January 2009, between two hostile political parties, 
the country has won praise from the international community as a beacon of hope and democracy and a model for the whole of Africa (Gyimah-Boadi 2009, Gyimah-Boadi \& Prempeh 2012).

However, unlike the 1996, 2000, 2004, and 2008 elections, which passed peacefully, with losers conceding defeat and congratulating the winner, the results of the 2012 elections, like those in 1992, were contested. In 1992 the credibility of the Electoral Commission of Ghana (ECG) was questioned and it was accused of colluding with the incumbent president. In 2012 the New Patriotic Party (NPP) accused the government of colluding with electoral officers to fraudulently manipulate electoral figures, taking the matter to the Supreme Court, which, in a judgement handed down on 29 August 2013, decided against the NPP's petition, with only two of the nine judges dissenting.

The dispute brought the country to the brink of violence.

Why are the outcomes of some elections broadly accepted by political players while others are strongly disputed? How do we explain variations in electoral outcomes in Ghana? How do we juxtapose Ghana's image as a political success story with strong formal institutions, particularly its Constitution and electoral laws, power alternation and democratic consolidation, with the resurgence of ethnic and regional conflicts and political polarisation, particularly after the 2012 elections? What roles do quasi-public entities or informal institutions play in enabling peaceful and credible elections? Are such roles able to bridge the gaps of ethnic, regional and political polarisation or do they feed into the political divide? These are the central issues this article interrogates.

Various studies have paid a great deal of attention to the importance of credible and peaceful elections, but the spotlight has largely fallen on the role of formal institutions. There is no doubt that formal institutions such as the Constitution, electoral laws, judiciary, political parties, electoral commissions and the security agencies, among others, play critical roles in the creation of peaceful and credible elections, however, the role of informal institutions or quasi-public entities deserves close attention too.

Drawing on Ghana's Inter-Party Advisory Committee (IPAC), a quasi-public entity (or informal framework for inter-party dialogue), this article argues that such entities play critical countervailing roles in the making of peaceful and credible elections. This is particularly so in a competitive multiparty democratic system where the stakes are extremely high and the agency responsible for conducting elections is generally perceived as partisan (see APRM 2005, para 34) and as characterised by strong ethnic and regional mobilisation for votes. The presence of informal institutions can mitigate the potential for excessive partisanship, ethnic and political polarisation and conflicts and can ultimately help avoid democratic breakdown and national disintegration. 
By contrast, the absence of such institutions may inflate these negative tendencies, increase the potential for ethnic and political violence and undermine social cohesion (see Gyimah-Boadi \& Asante 2006). Ghana's experience with informal institutions, particularly IPAC, enhances our understanding of variations in electoral outcomes in fragile democracies, especially in Africa.

In advancing this argument, the article is structured as follows: This introduction is followed by the theoretical foundations of the study and alternative explanations. The next section examines some of the key institutions adopted by Ghana to manage elections and diversity. The subsequent section looks at IPAC, emphasising its origins, functions and activities. It also provides a critical analysis of the strengths and weaknesses of IPAC, as well as its effectiveness as a framework for managing peaceful and credible elections in Ghana.

\section{THEORETICAL DEBATES AND EXPECTATIONS}

There has been a long-standing debate in political science about the viability of democracy in multi-ethnic and multicultural societies and some post-colonial and nationalist leaders in Africa, such as Kwame Nkrumah of Ghana, Ahmed Sékou Touré of Guinea, Kenneth Kaunda of Zambia, Julius Nyerere of Tanzania and, in the 1990s, Paul Biya of Cameroon, Yoweri Museveni of Uganda, and Jerry Rawlings of Ghana, claimed that ethnic diversity made democracy a bad fit for their countries.

Broadly, the debate may be classified into two main schools of thought: democracy-ethnic diversity pessimists and democracy-ethnic diversity optimists.

\section{Democracy-ethnic diversity pessimists}

Democracy-ethnic diversity pessimists argue that ethnic diversity or multiethnicity is detrimental to the maintenance of democracy. Adrian Karatnycky (2002, p 107) reinvigorated the debate when he concluded that 'democracy has been significantly more successful in mono-ethnic societies than in ethnically divided and multi-ethnic societies'.

Advocates of this view generally contend that ethnic differences polarise society and make compromise and consensus building difficult and, as a result, institutions cannot help with ethnic heterogeneity. Ancient Greek political philosophers such as Plato and Aristotle argued that pervasive inequalities and subcultures and cleavages (heterogeneity) are detrimental to the demos and a good political order (Merkela \& Weiffen 2012). John Stuart Mill (1806-1873) popularised this idea when he argued in the 16th chapter of his Considerations on Representative Government that: 
Free institutions are next to impossible in a country made up of different nationalities. Among a people without fellow-feeling, especially if they read and speak different languages, the united public opinion, necessary to the working of representative government cannot exist.

Mill 1861, p 289

According to Ernest Barker '.. in a multinational State the government either pits each nation against the rest to secure its own absolutism, or allows itself to become the organ of one of the nations for the suppression or oppression of others' (quoted by Connor 1967, p 33). As Robert Dahl (1989, p 207) succinctly puts it: 'The criteria of the democratic process presuppose the rightfulness of the unit itself.' Dahl (1971, p 108) also notes that:

Presumably because an ethnic or religious identity is incorporated so early and so deeply into one's personality, conflicts among ethnic or religious subcultures are especially fraught with danger, particularly if they are also tied to region ... That subcultural pluralism often places a dangerous strain on the tolerance and mutual security required for a system of public contestation seems hardly open to doubt. Polyarchy in particular is more frequently found in relatively homogeneous countries than in countries with a great amount of subcultural pluralism.

Donald Horowitz (1993, p 19) states that

[d]emocracy has progressed furthest in those East European countries that have the fewest serious ethnic cleavages (Hungary, the Czech Republic, and Poland) and progressed more slowly or not at all in those that are deeply divided (Slovakia, Bulgaria, Romania, and of course the former Yugoslavia).

In Asia it has been asserted that democracy is more robust in South Korea, which is more homogeneous than Indonesia. In Latin America it is also believed that democracy has flourished in Chile and Costa Rica, which are relatively homogeneous compared to Peru and Guatemala (Fish \& Brooks 2004, p 155).

\section{Democracy-ethnic diversity optimists}

Contrary to the opinion of democracy-ethnic diversity pessimists that ethnic diversity and democracy are incompatible and, as a result, institutions cannot 
help, various studies in recent times show that it is possible for democracy to be stabilised and even flourish in multiethnic societies (Fish \& Brooks 2004; Fearon and Laitin 2003; Young 1976, 2002). Democracy-ethnic diversity optimists believe that the issue of ethnicisation of politics is a political problem that requires a political solution within an institutional context. Institutions are thus held as the solution to the problems of multi-ethnicity in a democratising state. It is in this context that the idea that institutions matter has become a central pillar in the management of ethnic diversity, particularly in fragile democracies.

However, proponents of this view tend to emphasise strong formal institutions. For example, Donald Horowitz (1985, p 601) notes that formal institutions matter because they 'structure incentives for political behaviour'. Brendan O'Leary (2001) also stresses an institutionalist approach that focuses on constitutional and institutional design (see also O'Leary \& McGarry 1993). Paul Collier (1998) and William Easterly (2000) have also noted the importance of institutions in managing ethnic diversity and conflicts. For example, Easterly (2000, $\mathrm{p}$ ii) states that 'high quality institutions - reflected in such factors, such as rule of law, bureaucratic quality, freedom from government expropriation, and freedom from government repudiation of contracts - mitigate the adverse economic effects of ethnic fractionalization'. Others cite federalism and institutionalised political parties as key mechanisms for managing the ethnic factor in politics (Lijphart 1977; Bloomfield, Ghai \& Reilly 1998).

Still other scholars have noted the role played by presidential and parliamentary systems and other forms of constitutional engineering in moderating political attitudes and actions in ethnically divided society (Linz 1990a, 1990b, 1994; Horowitz, 1990). For example, Linz (1990a, 1990b, 1994) holds that parliamentarism is more flexible and creates a more conducive environment for a politically stable democratic transition than presidentialism, which is deemed to be too rigid and associated with various 'perils' such as polarising society, authoritarianism, personalisation of power and so on. Horowitz (1990), however, disagrees with this assertion, citing the case of Nigeria to show that presidentialism fosters a more effective institutional environment for promoting inter-ethnic harmony and peace than the Westminister model or parliamentarism.

In short, while the pessimists contend that institutions cannot help to stabilise democracy in multi-ethnic societies, the optimists believe that institutions are key to stabilising democracy in such societies. I advance the perspective of the optimists, arguing that institutions could have a stabilising effect, but, unlike the optimists, I emphasise informal institutions or socially shared rules created, communicated and enforced outside of officially sanctioned channels (Helmke \& Levitsky 2004). The reason for this is that since 1992 Ghana has put in place several important formal institutions and a legal framework for elections. 
The Constitution is the most important law governing elections in Ghana, but others include the election laws and statutory instruments pertaining to voter registration and presidential/parliamentary election; and constituency demarcation instruments, the Political Parties Act of 2000, the Local Government Act, the Electoral Commissions Act and relevant regulations developed by the ECG.

The Constitution provides for fundamental rights and freedoms and affirms the right to vote as one of those fundamental rights. It also establishes the elective offices and sets out the eligibility criteria for standing for president and for Parliament.

The ECG, an autonomous body comprising seven members, was established in 1993 by a statute in accordance with the provisions of the 1992 Constitution and has played a key role in managing elections in Ghana. However, the power of the president to appoint members of the commission has been a source of controversy among the parties.

When two members of the Interim National Electoral Commission were appointed after the controversial 1992 elections the then opposition NPP opposed the president's sole right of appointment and proposed political party representation on the commission. In 2004 the National Democratic Congress (NDC) challenged the intentions of the incumbent NPP president in appointing particular persons to vacant positions on the ECG in an election year even though the appointments conformed with the constitutional provisions.

Importantly, the Constitution contains elaborate provisions concerning the management of ethnic diversity. For example, the Directive Principles of State Policies frown on discrimination and the ethnicisation of politics and promote equality / equity in public sector governance (Republic of Ghana 1992). In addition, various laws in the Constitution and the Political Parties Act (2000) governing the activities of political parties also frown on ethnic mobilisation and bar ethnicbased parties. In addition, the judiciary plays an important role in settling electoral disputes.

I argue that the various formal institutions for managing elections in Ghana, most of which have been in existence since 1992, are important but not sufficient to guarantee credible and peaceful elections and the efficient resolution of electoral disputes, both in the pre- and post-election phase and, as such, should be complemented by informal institutions.

The missing link in the disputed elections of 1992 and 2012 was largely the result of the absence of a strong IPAC to deal with grievances and to promote confidence-building measures while moderating political tensions and excessive partisanship and ensuring a conducive political environment. The absence or weak presence of IPAC meant that political grievances with which it had previously dealt 
effectively played out in the courts and the media, generating further tensions and anxiety and poisoning the political environment.

For example, in July 2012, the four main political parties, the ruling NDC, the opposition NPP, the People's National Convention (PNC) and the Conventions People's Party (CPP) jointly sued the ECG over its insistence on proceeding with the by-elections in the Kwabre East and Wulensi constituencies using the old voters' register. The court ruled in favour of the parties, noting that the use of the old register for the by-elections could trigger electoral disputes (Myjoyonline. com 2012).

The strength (or lack of strength) of informal institutions such as IPAC is important in explaining the disputes and contestations that characterised the 1992 and 2012 elections despite the fact that the formal institutions were in place.

I set out three main theoretical expectations. Firstly, that the absence of quasipublic entities will lead to flawed elections and a surge in ethnic, regional and political conflict and will ultimately undermine social cohesion. Secondly, that the presence of strong quasi-public entities will enhance the quality and credibility of elections and reduce ethnic and regional tensions while strengthening social cohesion. Thirdly, the presence of weak quasi-public entities may lead to contested elections and a surge in ethnic regional conflicts and will ultimately undermine social cohesion.

Thus, the strong presence of IPAC in 1996, 2000, 2004 and 2008 contributed significantly to the successful elections despite the deep suspicion, new reforms and competitive nature of these elections, while its absence in 1992 and weakness in 2012 resulted in the flaws and disputes that characterised those elections.

\section{THE INTER-PARTY ADVISORY COMMITTEE}

In the late 1980s and early 1990s the Provisional National Defence Council (PNDC), led by Jerry Rawlings, which took power through a military coup d'état on 31 December 1981, came under both internal and external pressure to return Ghana to constitutional rule. Despite his initial reluctance Rawlings succumbed to the pressure, but the regime guided the transition process closely, excluding opposition parties from participating fully in the Constitution-drafting process and hand-picking members of the Committee of Experts set up to draft the Constitution. The PNDC also manipulated the composition of the Consultative Assembly that discussed the draft, in order to exclude independent voices, while refusing to allow a fully elected constituent assembly to undertake this task.

In the 1992 founding elections the opposition parties disputed the presidential election results and subsequently boycotted the parliamentary elections, which were held separately (Frempong 2012; Agyeman-Duah 2008; Boafo-Arthur 2007). 
There were a few pockets of violence around the country. In the interests of peace and stability the Commonwealth Observer Group recommended dialogue, even if it was informal (Frempong 2012), but the initial NDC-NPP dialogue failed because of deep mistrust between the two parties and suspicions about the electoral process (Frempong 2012, pp 62-63; Frempong 2007, 2008; Ayee 1997; Boafo-Arthur 2006). In March 1994 the ECG created IPAC, an informal and non-statutory body comprising representatives of political parties and of the ECG. ${ }^{1}$

The main functions of IPAC are: to serve as a channel of information for the commission and the parties and to enable them to discuss all aspects of the programme and activities of the commission with parties and donors; to ensure that parties and donors make an input into the management of the electoral process and, at the same time, bring out their concerns for general discussion; to facilitate regional, district and constituency level IPAC meetings (Open Society Initiative for West Africa - OSIWA - and the Institute for Democratic Governance - IDEG 2007 Ayee 1997a, 1997b; Frempong 2012).

Although IPAC's decisions are not binding on the ECG it has served as a forum for generating proposals for electoral reform and has succeeded in building trust in the electoral process, especially among political parties (Frempong 2012, pp 62-63; Frempong 2007; Ayee 1997). In response, the ECG, with donor support, embarked on a comprehensive programme of reforming the electoral process and enhancing its credibility.

Most starkly, through IPAC forums political parties participated in key electoral processes such as voter registration, development of the election Code of Conduct and the procurement of electoral materials. This resulted in the ECG largely succeeding in building confidence and achieving credible improvements in electoral management, leading to the conduct of four successful general elections with few complaints from the participants.

\section{IPAC interventions in elections}

Elections in Ghana are generally competitive and the political environment is often characterised by deep suspicions and anxieties among the political players and their supporters. This was the case in both 1992 and 1996. However, under the auspices of IPAC the main political stakeholders agreed on major electoral reforms prior to the 1996 elections: a single day for both parliamentary and presidential elections, photo-ID cards, voter photos on the electoral register and

1 It should be noted that the Institute of Economic Affairs (IEA) / Ghana Political Parties Programme (GPPP), formed in 2002, also brings together political parties with representation in Parliament and civil society organisations (CSOs) to discuss critical national issues. However, the GPPP is the subject of another article. 
transparent ballot boxes and the active involvement of party agents as observers of the registration exercise.

The reforms agreed to within IPAC were not binding on the ECG, nevertheless, it gave serious attention to suggestions and proposals that were practical, legal and cost effective (Frempong 2012). Since then, IPAC has become a framework for building trust and confidence within the political class on the conduct of elections and has also provided a platform for deepening trust in the ECG. By and large, IPAC succeeded in building confidence and has moderated excessive partisanship, political behaviour and actions of the key actors that have led to successful elections and less ethnic and political tension and have enhanced social cohesion.

Although the 2000 elections, too, were characterised by deep mistrust among the parties, IPAC continued with its confidence-building measures and moderation of political activities and behaviour and this resulted in another successful election and the alternation of power, with John Evan Atta Mills, the ruling NDC's presidential candidate, conceding defeat to the NPP candidate, John Kuffuor. The post-election environment was peaceful and the losing candidates conceded defeat, congratulated the victor and subsequently participated in the inauguration of the president, minimising ethnic and political tensions and fostering national unity (Gyimah-Boadi 2001).

Mistrust was evident in 2004 too, despite major electoral reforms announced by the ECG. One source of controversy was the creation of 30 additional constituencies for the election, increasing the number of seats in Parliament from 200 to 230 . Once more IPAC succeeded in building confidence and consensus and the election was successful.

By 2008 IPAC had gained widespread recognition among the political actors, the public, donors and election observers, with both European Union and African Union observers suggesting it should be institutionalised. Once more power changed hands without conflict when Atta Mills defeated Nana Akuffo-Addo of the NPP by less than $0.5 \%$ in a run-off after Akuffo-Addo had won the first round by about $2 \%$, falling short of the $50 \%$-plus-one threshold.

Ghana's democratic credentials and ethnic harmony and social cohesion remained intact, winning praise for the country from the international community as a political success story and a model of electoral democracy for the whole of Africa.

Constant discussions among the ECG, political parties and the donor community and advice to the ECG yielded new ideas, resulting in progressive improvements in the electoral process. For example, in the 2000 and 2004 elections parties were represented at the various printing houses where ballot papers were printed. The ECG, through IPAC, discussed not only the electoral roadmap but also new reforms and changes prior to their implementation. 
For instance, in October 2003 the ECG informed IPAC of the 30 additional constituencies (Ghanaweb 2003). It also announced to IPAC that a voter registration exercise would take place in January 2004 and that, in conformity with Article 451 of the Constitution, it had set up a procurement committee with representatives from the donor community and the Ministry of Finance and Economic Planning, which had completed the evaluation of bids for the procurement of electoral materials for the voter registration exercise and the 2004 elections (Ghanaweb 2003).

The ECG also proposed to set up a six-member committee comprising two representatives each from the ECG and the political parties (one from the governing party and one from an opposition party), a representative each from the Ministry of Finance and Economic Planning and the donor community, which would serve as an expert or consultant on the procurement of electoral materials. However, the parties declined to serve on the committee, stating that 'there had not been any indication of malfeasance on the part of the ECG to suggest that the commission was incompetent and inefficient in handling the procurement of electoral materials and that the commission should be allowed to take responsibility for its actions' (Ghanaweb 2003).

On that basis the parties 'agreed at the meeting that once the IPAC is informed of the process of procurement and items of deliveries the fears of political parties would be allayed and their interest secured'. In this regard, '[t]he parties again suggested that instead of their participating in a procurement committee the commission should put in place a five-member committee made up of three ECG representatives and two others from the donor community' (Ghanaweb 2003). Clearly, the involvement of the political parties in all aspects of the electoral process gave them the feeling that they had a stake in the process and that it was therefore binding on them. Consequently, they played an active role in ensuring the success of all electoral activities.

IPAC's interventions in the 2008 elections were equally crucial in assuaging the anxieties and tensions that emerged following concerns raised by the opposition NDC that the voters' register in the Ashanti Region, the stronghold of the NPP, was bloated and the call for an IPAC meeting to look into the issue. The NDC threatened to contest the outcome of the elections if its concerns were not addressed by IPAC and the ECG.

The NDC also vehemently opposed the Representation of the People Amendment Bill, which the NPP had tabled in 2004. In terms of the Bill the Representation of the Peoples Law of 1992 (PNDC Law 284) would be amended to enable Ghanaians residing abroad to register and vote in elections. Again, the NDC threatened to contest the election results if the Bill was passed (OSIWA and IDEG 2007). Through the efforts of IPAC and other CSOs the issues raised by the 
NDC were discussed with the ECG and resolved, calming tensions around the organisation of the December 2008 elections.

The head of the European Union Election Observer Mission (EU-EOM), Nickolay Mladenov, stated in the final report on election 2008 that the IPAC meeting should be developed as a more regular platform of dialogue between the Electoral Commission and the political parties' (Hayford nd). Similar recommendations were made by the election observer missions of the African Union and the Economic Community of West African States, with some suggesting once more that IPAC should be institutionalised.

Indeed, delegations from other African countries such as Nigeria (UNDP 2012) and Uganda (Ghana News Agency 2013) have visited Ghana to learn more about IPAC and inter-party dialogue. Political parties in Ghana have also suggested that IPAC should be guaranteed by law in the same way as the Council of State that advises the president on important national issues (Ghana News Agency 2011).

\section{IPAC and elections 2012}

Successful and pragmatic interventions in the 1996, 2000, 2004 and 2008 elections earned IPAC recognition and acceptance both domestically and internationally as a major innovation and instrument for inter-party dialogue, building confidence, moderating political behaviour, actions and activities and promoting political stability. Against the background of its growing popularity many Ghanaians were optimistic that IPAC would continue to play an influential role in promoting credible and peaceful elections in 2012. Shockingly, the ECG sidelined IPAC when it made major electoral reforms and decisions about the 2012 elections.

Instead of convening regular IPAC meetings to deliberate on electoral reforms and a new roadmap, the ECG issued declarations and directives through the media and press conferences, to the disappointment of the political parties. For example, in March 2011 a workshop on how to strengthen inter-party dialogue in Ghana organised by International IDEA, in collaboration with the ECG, and attended by representatives of all political parties, provided a platform for political parties to reflect on the challenges facing IPAC and to make recommendations to improve its effectiveness (IDEA 2011).

During the workshop the parties expressed concerns about the infrequency of IPAC meetings, which, they felt, deprived them of the opportunity to understand the ECG's ongoing programme (IDEA 2011). The parties said they were 'keen to be kept informed about plans for biometric registration. The parties also thought they could be consulted on matters relating to district-level elections' (IDEA 2011), indicated that the ECG was sometimes heavy handed and intolerant in 
its chairing of IPAC meetings and called for the leaders of the ECG to respect the decisions of IPAC, especially in cases where parties generally agreed about a particular issue (IDEA 2011).

By sidelining IPAC and resorting to unilateral decisions, often supported by the ruling NDC, the ECG was locked into a long-drawn-out debate with the opposition parties, particularly the NPP, as well as several non-governmental organisations, over some of the new reforms, particularly the introduction of the biometric electoral register and verification system.

The creation of 45 new constituencies just weeks before the elections drew strong criticism from the clergy, student groups and the opposition parties, especially the NPP, who described the move as gerrymandering. The political environment was further poisoned by the consistent support the ECG received from the ruling NDC with regard to many of the controversial issues. As a result, changes announced by the ECG were interpreted as laying the groundwork for election rigging.

Ghana has a constituency-based first-past-the-post (FPTP) electoral system and the ECG has jurisdiction over the review of the constituency boundaries and creation of new constituencies. Shortly before the elections the commission embarked on a delimitation exercise through which it increased the number of constituencies from 230 to $275 .{ }^{2}$ In a similar exercise in 2004 the ECG announced the changes during an IPAC meeting. In 2012 the ECG made the announcement at the Ghana International Press Centre in Accra (Daily Guide 2012), astonishing political parties and civil society groups.

The news drew swift criticism from the opposition parties, who argued that they had not been consulted and the matter had not been discussed at IPAC, but it was welcomed by the NDC. The opposition parties cautioned the ECG about its sidelining of IPAC, stating that if it acted unilaterally this could lead to the electoral process being discredited. An attempt by a group of citizens to get a court ruling to prevent the ECG from creating the new constituencies failed.

At a press conference the NPP stated that the 'minority and the NPP are not against the creation of new constituencies per se, [but that] the process and timing is reprehensible' (RadioXYZonline 2012). The NPP demanded, unsuccessfully, that a meeting of IPAC be held immediately 'to resolve thorny issues bedevilling the biometric registration in the country' (RadioXYZonline 2012). The minority leader, Osei Kyei-Mensah-Bonsu, lamented that the process of creating constituencies had been fraught with so many problems that it was unreasonable to continue with it.

Earlier in August the majority in Parliament had been forced to spike the

2 The roles of the Local Government Ministry, which creates administrative districts and the Electoral Commission, which creates constituencies, overlap. 
document, known as $\mathrm{CI} 73$, which contained the regulations for the creation of the new constituencies, when the subcommittee responsible for looking into its contents complained that it was riddled with inaccuracies. The original document was withdrawn and a new one, CI 77, was tabled, only to be withdrawn and replaced with a third document. The minority leader described the way in which the ECG and the majority party tried to force CI 73 through as 'a complete illegality [which] clearly portrays the ECG as being in bed with the NDC government' (RadioXYZonline 2012).

He noted further that, '[t]he Electoral Commission knows that as we speak today there are no new constituencies in place, yet the ECG went ahead and supervised the conduct of the primaries by the ruling government party in these non-existent constituencies' (RadioXYZonline 2012). Such actions, he said, might make people suggest that the ECG and the government had malicious intentions. The minority said CI 73 had been put together in haste and it was time civil society groups intervened and demanded that the 'powers that be' change their position on the matter (RadioXYZonline 2012).

The minority leader urged the ECG to focus instead on CI 75, which regulated the biometric register and voting system, in order to forestall problems related to the ongoing display of the voters' register. In order to ensure credible and fair elections, the minority leader suggested, 'this is not a time for ordinary prayers' but one for all to discuss this 'vain experimentation' in order to curb any potential problems (RadioXYZonline 2012).

Biometric voter registration (BVR) was a major reform announced by the ECG for the purposes of the 2012 elections. The commission argued that the BVR and biometric voter verification (BVV) would speed up the electoral process and reduce queuing time, while also ensuring total accuracy by providing useful election-day statistics and further enhancing confidence in the elections. The voter registration exercise was carried out from 24 March to 5 May 2012, during which period about 14.3-million voters were registered.

However, like the creation of the new constituencies, the introduction of the BVR was not adequately discussed by IPAC. Much of the information about the process was disseminated through the media, resulting in mounting criticism of the ECG. The parties expressed concern about the commission's delay in convening an IPAC meeting to deliberate on the methods and procedures for the implementation of the biometric exercise and related processes.

In a letter to the ECG the NPP stated: 'We wish to convey our deep sense of apprehension that the manner in which you are conducting affairs towards the 2012 elections, secretly, stealthily and silently is a recipe for disaster' (The Chronicle nd). It stated further: 'We realize that your institution has no experience in the field of electoral biometrics and you have not requested credible experts to help 
you in undertaking this exercise' (The Chronicle nd). Failure to do so could lead to a flawed outcome, wrote the NPP.

In order to avoid this, it posited, 'There is an urgent need to convene IPAC immediately so that together we can help restore credibility ... We refer you to our previous correspondence on the need to get IPAC convened and deliberating on matters regarding the forthcoming Biometric Voter Registration exercise and other issues pertaining to the 2012 general elections' (The Chronicle nd). The opposition noted that its call for specific information and material to enable it to convince itself that the 'tender process' leading to the procurement of equipment and materials was credible had fallen on deaf ears.

The debate was, however, eventually resolved with the introduction of the principle of no verification, no vote (NVNV).

Despite the benefits of the biometric system there were major setbacks during the registration period.

Partly due to misinformation and poor publicity on the part of the ECG there were tensions in some centres as a result of people moving from areas where the exercise was yet to be conducted. There were reports of malfunctioning printers and laptops and thumbprint machines. These technical problems, in addition to the late arrival of officers, delayed registration in some areas.

Ineffective communication of the schedules for the registration exercise added to the frustration of some applicants, who visited registration centres which were not included in the first phase of the exercise, scheduled for 24 March to 2 April.

There were clashes among party members and agents over irregularities relating to the poor understanding and application of eligibility criteria for registration, particularly with regard to place of residence, age, identification and procedures for guarantors. In the Odododiodio constituency in Accra the process became chaotic when NDC agents turned away people they claimed did not live in the constituency. The NPP's parliamentary candidate for Ablekuma South, Ursula Owusu, and the spokesperson for Nana-Akufo Addo, Samuel Abu Jinapor, were allegedly attacked by the same agents. There were also clashes in the constituency between supporters of the NDC and the NPP.

Discussions in the media about this incident became ethnicised because it was alleged that those who were turned away had particular names or were perceived to come from particular ethnic groups.

These unfortunate developments, coupled with the failure of the police to act swiftly, further heightened ethnic tensions and severely poisoned the pre-election political environment, especially when a leading member of the NPP called on supporters of the party in some regions to attack NDC supporters.

In response to these tensions and challenges IPAC, civil society and the 
political parties called on the ECG to address all the problems before the elections, but, despite assurances from the ECG that this would be done, election day produced further problems, which are detailed in other articles in this issue of the journal.

\section{CONCLUSION}

This article has examined why some elections in Ghana went smoothly, with the results broadly accepted by key political players, while others did not. It shows that since the re-introduction of multiparty politics in 1992 Ghana has put in place various formal institutions for managing elections and has held six successive elections, the results of four of which were broadly accepted by the main political players. Those in 1992 and 2012, however, were disputed, despite the fact that the formal institutions have remained largely the same throughout all the elections.

The Inter-Party Advisory Committee was established to ensure that the technical, operational and logistical challenges encountered in the 1992 elections were tackled. I have shown that the absence of IPAC in 1992 led to the flawed election and the contestations and ethnic and political tensions that followed that election.

In contrast, IPAC's presence in 1996 significantly enhanced the quality and credibility of the elections, reducing ethnic and political tensions and strengthening social cohesion. Finally, the sidelining of IPAC largely explains the disputes and the resultant surge in ethnic and political conflict that brought the country to the brink of violence after the 2012 elections.

Clearly IPAC is a forum that promotes transparency in the electoral process and a place where political players can share ideas and advise the ECG on electoral issues. Importantly, IPAC has collaborated with other civil society groups, such as churches, the media and the National Peace Council, to set in motion incremental changes and improved mechanisms to ensure peaceful, fair and credible elections. This has enabled Ghana to achieve a progressive improvement in electoral management and the increasing acceptance of election results by key political actors and observers alike.

As noted, through IPAC forums political parties participated in key electoral processes such as voter registration, the development of the electoral Code of Conduct, procurement of election materials, printing of ballot papers, development of the Political Parties Code of Conduct and negotiated a framework for peace known as the Kumasi Accord (signed on 27 November 2012) that commits election stakeholders to peaceful elections.

IPAC's activities also engendered confidence in and goodwill towards the electoral commission. However, unlike in the four previous elections, in 2012 
IPAC was sidelined by the ECG and thus failed to promote the kind of confidencebuilding measures expected of it.

It also failed to deal with all the grievances and anxieties that emerged prior to the elections and heightened tensions, especially in the implementation of the biometric voting system and constituency delimitations, leading to disputed elections and increased ethnic and political tensions.

The intransigence of the ECG meant that previous grievances and issues that were resolved peacefully through IPAC were allowed to play out in the media and the courts. In light of the ongoing disputes and the challenges that bedevilled the 2012 elections Ghana needs to embark on major electoral reforms. This would require careful consideration of strengthening the role of IPAC, which is currently weak, poorly structured and has no funding for its activities.

\section{- REFERENCES -}

African Peer Review Mechanism. 2005. Country Review Report and Programme of Action of the Republic of Ghana.

Agyeman-Duah, B. 2008. 'Fifty Years in Perspective'. In B Agyeman-Duah (ed). Ghana: Governance in the Fourth Republic. Accra: Ghana Centre for Democratic Development.

Ayee, J R A. 1997a. 'The 1996 general elections: An overview'. In J R A Ayee (ed). The 1996 General Elections and Democratic Consolidation in Ghana. Accra: Department of Political Science, University of Ghana.

Ayee, J R A. 1997b. 'Elite consensus and democratic consolidation in Ghana: The inter-party advisory committee IPAC'. In J R A Ayee (ed). The 1996 General Elections and Democratic Consolidation in Ghana. Accra: Department of Political Science, University of Ghana.

Bloomfield, D, Y Ghai \& B Reilly. 1998. 'Analysing deep-rooted conflict'. In P Harris \& B Reilly (eds). Democracy and Deep-Rooted Conflict: Options for Negotiators 8. Stockholm: International Institute for Democracy and Electoral Assistance (International IDEA).

Boafo-Arthur, K (ed). 2006. Voting for Democracy in Ghana: The 2004 Elections in Perspective Vo1 1. Accra: Freedom Publications.

Boafo-Arthur, K. 2007. Ghana: One Decade of the Liberal State. New York: Zed Books. Chronicle, The. nd. 'NPP writes to Electoral Commission'. Available at: thechronicle. com.gh/npp-writes-to-electorial-commission-2/

Collier, P. 1998. 'The Political Economy of Ethnicity'. Paper prepared for the Annual World Bank Conference on Development Economics, Washington, D C, 20-21 April 20-21. Available at: www.csae.ox.ac.uk/workingpapers / pdfs / 9808text.pdf 
Connor, W. 1967. 'Self-determination: The New Phase'. World Politics 201.

Dahl, R A. 1971. Polyarchy: Participation and Opposition. New Haven/London: Yale University Press.

Dahl, R A. 1989. Democracy and its Critics. New Haven/London: Yale University Press.

Daily Guide. 2012. 'ECG Creates 45 New Constituencies'. Available at: www. modernghana.com/newsthread1/401456/1/

Easterly, W. 2000. Can Institutions Resolve Ethnic Conflict? World Bank Policy Research Working Paper No 2482, February. Available at: www-wds. worldbank.org/servlet/WDSContentServer/WDSP / IB / 2000/12/15/000 094946_00111805313095/Rendered/PDF / multi_page.pdf

Easterly, W \& R Levine. 1997. 'Africa's growth tragedy: Policies and ethnic divisions'. Quarterly Journal of Economics 112.

Fearon, J D \& D D Laitin. 2003. 'Ethnicity, insurgency, and civil war'. American Political Science Review 972.

Fish, MS \& R S Brooks. 2004. 'Does diversity hurt democracy?'. Journal of Democracy 151.

Frempong, A K D. 2007. 'Political conflict and elite consensus in the liberal state'. In K Boafo-Arthur (ed). Ghana: One Decade of The Liberal State. New York: Zed Books.

Frempong, A K D. 2008. 'Innovations in electoral politics in Ghana's Fourth Republic: An analysis. In C Raventos (ed). Democratic Innovation in the South: Participation and Representation in Asia, Africa and Latin America. Buenos Aires: CLACSO Books.

Frempong, A K D. 2012. Electoral Politics in Ghana's Fourth Republic: In the Context of Post-Cold War Africa. Accra: Yamens Press Limited.

Ghana News Agency. 2013. 'Leaders Of Ugandan Political Parties Meet With Ghanaian Counterparts'. Available at: www.ghana.gov.gh/index.php/201202-08-08-32- 47/ general-news/1662-leaders-of-ugandan-political-partiesmeet-with-ghanaian-counterparts

Ghanaweb.com. 2003. '230 MPs in 2004?. Available at: www.ghanaweb.com/ GhanaHomePage/ NewsArchive/ artikel.php?ID $=47972$

Gyimah-Boadi, E. 2001. 'A peaceful turnover in Ghana'. Journal of Democracy 12.

Gyimah-Boadi, E. 2009. 'Another step forward for Ghana'. Journal of Democracy 202. Gyimah-Boadi, E \& H K Prempeh. 2012. 'Oil, politics, and Ghana's democracy'. Journal of Democracy 233.

Gyimah-Boadi, E \& R Asante. 2006. 'Ethnic structure, inequality and public sector governance'. In Y Bangura (ed). Ethnic Inequalities and Public Sector Governance. New York: Palgrave MacMillan.

Hayford, K A. n.d. 'Is IPAC losing its focus towards electoral transparency?'. 
Available at: thechronicle.com.gh/is-ipac-losing-its-focus-towards-electoraltransparency/

Helmke, G \& S Levitsky. 2004. 'Informal institutions and comparative politics: A research agenda'. Perspectives on Politics 2(4).

Horowitz, D L. 1985. Ethnic Groups in Conflict. Berkeley: University of California Press.

Horowitz, D L. 1990. 'Comparing democratic systems'. Journal of Democracy 14. Horowitz, D L. 1993. 'Democracy in divided societies'. Journal of Democracy 4.

International IDEA. 2011. 'Improving inter-party dialogue in Ghana'. Available at: www.idea.int/africa/ghana_party_dialogue.cfm

Karatnycky, A. 2002. 'Muslim countries and the democracy gap'. Journal of Democracy 131.

Lijphart, A. 1977. Democracy in Plural Societies: A Comparative Exploration. New Haven: Yale University Press.

Linz, J. 1990a. 'The perils of presidentialism'. Journal of Democracy 11.

Linz, J. 1990b. 'The virtues of parliamentarism'. Journal of Democracy 14.

Linz, J. 1994. 'Presidential or Parliamentary Democracy: Does It Make a Difference?'

In J Linz \& A Valenzuela (eds). The Failure of Presidential Democracy. Baltimore, MD: Johns Hopkins University Press.

Merkela, W \& B Weiffen. 2012. 'Does heterogeneity hinder democracy?' Comparative Sociology 11.

Mill, J S. 1861. Considerations on Representative Government. Oxford: Oxford University Press [1974].

Mill, J S. 1861. Considerations on Representative Government. London: Parker.

Myjoyonline.com (2012). 'Court stops ECG from holding Wulensi and Kwabre West by-elections'. Available at: politics.myjoyonline.com/pages / news / 201207/91138.php

O'Leary, B. 2001. 'Nationalism and ethnicity: Research agendas on theories of their sources and their regulation'. In D Chirot \& M E P Seligman (eds). Ethnopolitical Warfare: Causes, Consequences and Possible Solutions. Washington, D C: American Psychological Association.

O'Leary, B \& J McGarry (eds). 1993. The Politics of Ethnic Conflict Regulation. London: Routledge.

Open Society Initiative for West Africa and the Institute for Democratic Governance. 2007. Ghana Democracy and Political Participation: A review. AfriMAP.

RadioXYZonline.com. 2012. 'ECG in bed with NDC government - Minority Leader'. Available at: edition.radioxyzonline.com/pages / election/09052012-1114/5564.stm

Republic of Ghana. 1992. Constitution of the Republic of Ghana, 1992. Tema: Ghana 


\section{Publishing Corporation.}

Republic of Ghana 2000. Political Parties Act 2000. Accra: Assembly Press.

UNDP. 2012. 'Democratic governance for development project': e-newsletter. Availaable at:www.ng.undp.org/dgd/newsletter/February-March2012.pdf Young, C. 1976. The Politics of Cultural Pluralism. Madison and London: The University of Wisconsin Press.

Young, C. 2002. 'Deciphering disorder in Africa: Is identity the key?' World Politics 544 . 